\title{
THE EFFECT OF COOPERATIVE LEARNING MODEL TYPE TEAMS GAMES TOURNAMENT (TGT) ON STUDENT ACHIEVEMENT ON HEAT AND TEMPERATURE TOPIC IN CLASS X SMA N 1 BERASTAGI AT ACADEMIC YEAR 2012/2013
}

\author{
Rita S Situmorang dan Sahyar \\ Situmorangrita44@yahoo.co.id \\ Jurusan Fisika FMIPA Universitas Negeri Medan \\ Jalan Willem Iskandar Pasar V Medan, 20221
}

\begin{abstract}
This study set out to investigate cooperative learning effect on students' achievement in Physics Topic. observation and hypothesis testing at 0.05 level of significance were formulated to guide the study. The study adopted a quasi-experimental design. Two hundred and eighty eight (288) students of the schools SMA N 1 Berastagi constituted the population. An achievement test items, 20 in number was used for data collection. Mean Standard Deviation and Activity of student's were used to answer the research question while t-test was used to test the hypothesis and the average every meeting was used to test the activity. The result of the analysis of data collected on the research question showed that students of the Teams Games Tournament group have better achievement than the Direct Instruction group.
\end{abstract}

Keyword : Teams Games Tournament, Student Achievement, Activity, Physics

\section{INTRODUCTION}

Education in schools is aim to improve learning outcome and learning activity especially in Physics lesson ( Sudjana, 2009). Education is very important in daily life. The lack of student motivation to develop their ideas and weakness on learning during the learning process is being rapidly increased as the main problem facing on our national education now days. A good learning process is centered learning to students. Student centered learning could enabling students in teaching. Students can understand the lesson through the experience gained in learning. Otherwise few of students can master a lesson when students are only accepted from what is conveyed by the teacher. Therefore we need a method of learning that can attract students' interest in learning. The method in question is the method cooperative learning.

Cooperative Teams Games Tournament is organizational strategy which can be used in any subject 
matter area. Students are placed in four member heterogeneous teams. They receive a teacher directed lesson, help one another master the material, and compete in weekly tournaments. The tournaments are organized by "tables" of three similarly achieving students from different four member teams. In other words, high achieving students are regrouped to compete with other low achieving students; low achieving students compete with other low achieving students. The winner of a tournament table earns points for his or her original four person team. High scoring teams receive team rewards like certificates or other group recognition (De Vries, 1972).

Learning is the acquisition of habits, knowledge, and attitudes. It involves new ways of doing things, and it operates in an individual's attempts to overcome obstacles or to adjust to new situations. It represents progressive change in behavior as the individual reacts to a situation or situations in an effort to adapt his behavior effectively to demands made upon him. It enables him to satisfy interests or to attain goals. Learning may be vertical and horizontal, vertical in so far as precision in performance is increased or information is added to that already learned, horizontal in so far as what is learned is integrated and organized as a part of a functioning unit of expanding experience.

According to Fredrickson \& Branigan, in Seligman (2009), Learning is understands a new things and learn better ways to do many things. Learning means to observe something, ask about it, read about it, so you get the knowledge about it. One obstacle in learning is to learn something without looking at the shape of the object that you're learning, so it make students have difficulties is learning. Learning without knowing the form of objects that are learned can make students feel stupid, embarrassed, bored, or angry. Read a book or listening to someone talk is not going to members of students being required. Therefore it takes the form of the object being studied. (Fredrickson \& Branigan, 2005)

Cooperative learning refers to instructional methods in which teachers organize students into small groups, which then work together to help one another learn academic content. Cooperative learning methods are extensively researched and under certain well-specified conditions they are known to substantially improve student achievement in most subjects and grade levels, yet the structured forms of cooperative learning that have proven to be effective are not used as often as more informal forms. Further, there remains considerable debate about the theoretical basis for achievement outcomes of cooperative learning. This chapter reviews and integrates evidence on the theoretical mechanisms relating to learning outcomes of cooperative learning, and presents evidence on the most widely used practical applications of cooperative methods.

Cooperative learning methods vary widely in their details. Group sizes may be from two to several. Group members may have individual roles or tasks, or they may all have the 
same task. Groups may be evaluated or rewarded based on group performance or the average of individual performances, or they may simply be asked to work together.

Teams-Games-Tournaments is a six step process which moves from a teacher-selected topic to developing a list of questions related to the topic. The questions and small pieces of paper are numbered. One student in each group reads the questions as the numbers are drawn from a pile. The "game" begins when students placed in heterogeneous groups are given a letter identity and a number identity. Students must answer the questions they are matched with but may turn to a team member if an answer is not known. The tournament phase is structured by the teacher to place students in like groups (e.g. low achieving, high achieving). For every question a student answers correctly, a point is earned. Then students return to their game group and report their scores. Team scores are compared and winning teams earn a reward. Finally, the teacher may conduct an additional individual assessment. (Slavin, 2005)

Teams-Games-Tournament (Slavin, 2005) uses the same teacher presentations and teamwork as in STAD, but replaces the quizzes with weekly tournaments. In these, students compete with members of other teams to contribute points to their team score. Students compete at three-person "tournament tables" against others with a similar past record in mathematics. A procedure changes table assignments to keep the competition fair. The winner at each tournament table brings the same number of points to his or her team, regardless of which table it is; this means that low achiever (competing with other low achievers) and high achievers (competing with other high achievers) have equal opportunity for success. As in STAD, high performing teams earn certificates or other forms of team rewards. TGT is appropriate for the same types of objectives as STAD. Several studies of TGT have found positive effects on achievement in math, science, and language arts (Slavin, 2005).

Student's achievement is the result achieved by students who have followed the teaching-learning process. The result is something that is essentially derived from an activity, while learning is a process that resulted in changes to the individual, i.e, changes in behavior, both aspects of knowledge, skill, and aspects of his attitude. Student's achievement is a term used to indicate the level of success achieved by students in a particular field of study after participating in the learning process.

According to Sudjana (2009): Student's achievement are the abilities of the students after receiving their learning experience. Meanwhile, according to Horwart Kingsley in book of Sudjana devide three kinds of studen's achievement: (1) Skills and habits; (2) Knowledge and guidance, and; (3) Attitudes and ideals (Sudjana, 2009).

According Dimyati and Mudjiono (2002), learning outcomes are to be viewed from two sides of the side of the students and teachers. From the students, learning outcomes is the level of mental development better than the time before learning. 
Level of mental perkembagan better than the time before learning. The level of mental development is manifested in the types of cognitive, affective, and psychomotor. In terms of teachers, the results of the current study is the completion of study materials Based on Bloom's Txonomy theory of learning result, there are three categories of domains including cognitive, affective, and psychomotor.

\section{RESEARCH METHOD}

\section{Research Instrument}

Research instrument in this research in order to collect student achievement data on heat and temperature topic consist of 20 question of multiple choice form with five options. The question will be give to sample class, to test the validity. The validity of this research instrument is contents validity, with 3 validator which are 2 person Physics Lecture and 1 is teacher RSBI State Senior High School 1 Berastagi.

\section{Observation}

Observations carried on the teaching and learning activities by the observer is straightforward and conducted by researchers and was supported by two fellow researchers and assessment criteria based on the observation of students' learning activities. Student activity is observed during the learning process takes place.

\section{Hypothesis Test}

Hypotesis test calculate wih 2 kinds are :

\section{Pre-test ability Test (two tail test)}

$\mathrm{T}$ test is used to determine the similar ability student in both of groups sample

The form of hypothesis will be test is:

$\mathrm{H}_{0}: \mu_{1}=\mu_{2}$ : Experiment class and control class have same similarity of ability

$\mathrm{H}_{0}: \mu_{1} \neq \mu_{2}:$ Experiment class and control class have not same similar ability

If research data have normal distribution and homogent, test of hypothesis will use t-test with formula

$$
t=\frac{\overline{X_{1}}-\overline{X_{2}}}{S \sqrt{\frac{1}{n_{2}}+\frac{1}{n_{2}}}}
$$

(Sudjana, 2002)

With $\mathrm{S}$ is combination of deviation standard can calculate with the formula according to Sudjana (2002):

$$
S^{2}=\frac{\left(n_{1}-1\right) S_{1}^{2}+\left(n_{2}-1\right) S_{2}^{2}}{n_{1}+n_{2}-2}
$$

where:

$$
\begin{aligned}
\overline{X_{1}}= & \text { The average value of learning } \\
& \begin{array}{l}
\text { outcomes in the experiment } \\
\text { class }
\end{array} \\
\overline{X_{2}}= & \text { The average value of learning } \\
& \text { outcomes in the control class } \\
n_{1}= & \text { Total experiment class sample. } \\
n_{2}= & \text { Total control class sample. } \\
\mathrm{S}^{2}= & \text { Varians two of class } \\
\mathrm{t}= & \text { Value of } \mathrm{t}
\end{aligned}
$$

With the criteria is:

$\mathrm{H}_{0}$ accept if $-t_{1-1 / 2^{\alpha}}<t<t_{1-1 / 2^{\alpha}}$ where $t_{1-1 / 2^{\alpha}}$ we get from $\mathrm{t}$ list with $\mathrm{dk}=$ 
$\mathrm{n}_{1}+\mathrm{n}_{2}-2$ and probability $\left(1-\frac{1}{2} \alpha\right)$. To another value of $t \mathrm{H}_{0}$ not accept.

Value of $t_{\text {calculate }}$ compare with $\mathrm{t}^{-}$ table get from $t$ table list to $a=0,05$. If $-t_{1-1 / 2^{\alpha}}<t<t_{1-1 / 2^{\alpha}}$ on the level $\alpha=0,05$ and independent degree $d \mathrm{k}=\mathrm{n}_{1}+\mathrm{n}_{2}-2$, so have the same initial ability of student.

Ha accept if $t_{\text {calculate }}>t_{\text {table }}\left(t_{\text {table }}\right.$ get from distribution $t$ list for $\alpha=0,05)$, it is mean have not same initial ability of student.

If $\mathrm{S}_{1} \neq \mathrm{S}_{2}$, so, $\mathrm{t}$ test formula will be use is:

$t^{\prime}=\frac{\bar{X}_{1}-\bar{X}_{2}}{\sqrt{\left(S_{1}^{2} / n_{1}\right)+\left(S_{2}^{2} / n_{2}\right)}}$

With test criteria : accept $\mathrm{H}_{0}$ if:

$-\frac{w_{1} t_{1}+w_{2} t_{2}}{w_{1}+w_{2}}<t^{\prime}<\frac{w_{1} t_{1}+w_{2} t_{2}}{w_{1}+w_{2}}$

with $w_{1}=S_{1}^{2} / n_{1} ; w_{2}=S_{2}^{2} / n_{2}$

$t_{1}=t_{(1-1 / 2),\left(n_{1}-1\right)} ; t_{2}=t_{(1-1 / 2 \alpha),\left(n_{2}-1\right)}$

\section{a. Post-test ability test}

T-test two parts used to knowing effect of treatment its cooperative learning model type Teams Games Tournament (TGT) on student's achievement.

The form of hypothesis will be test is:

$\mathrm{H}_{0}: \mu_{1} \leq \mu_{2}:$ Cooperative Learning Model Type Teams Games Tournament is not have effect to student learning achievement.

$\mathrm{H}_{0}: \mu_{1}>\mu_{2} \quad$ : Cooperative Learning Model Type Teams Games Tournament have effect to student learning achievement..

If distribution normal data have the variance homogeny so the hypothesis in the research use $t$ test with the formula is :

$$
t=\frac{\overline{X_{1}}-\overline{X_{2}}}{S \sqrt{\frac{1}{n_{1}}+\frac{1}{n_{2}}}}
$$

With:

$$
S^{2}=\frac{\left(n_{1}-1\right) S_{1}^{2}+\left(n_{2}-1\right) S_{2}^{2}}{n_{1}+n_{2}-2}
$$

With test criteria is :

Ho accept if $\mathrm{t}_{\text {calculate }}<\mathrm{t}(1-\alpha)$ where $t_{(1-\alpha)}$ get from distribution table $t$ with independent degree $(\mathrm{dk})=\mathrm{n}_{1}+\mathrm{n}_{2}-2$ and the probability $(1-\alpha)$ with $\alpha=$ 0,05 for another value of $t$ Ho not accept, so Cooperative Learning Model type Teams Games Tournament have effect to student learning achievement. If $\mathrm{S}_{1} \neq \mathrm{S}_{2}$, so the formula t test will use

$$
t^{\prime}=\frac{\bar{X}_{1}-\bar{X}_{2}}{\sqrt{\left(S_{1}^{2} / n_{1}\right)+\left(S_{2}^{2} / n_{2}\right)}}
$$

Test criteria not accept is : not accept $\mathrm{H}_{0}$ if:

$$
t^{\prime} \geq \frac{w_{1} t_{1}+w_{2} t_{2}}{w_{1}+w_{2}}
$$

with $w_{1}=S_{1}^{2} / n_{1} ; w_{2}=S_{2}^{2} / n_{2}$

$$
t_{1}=t_{(1-\alpha),\left(n_{1}-1\right)} ; t_{2}=t_{(1-\alpha),\left(n_{2}-1\right)}
$$




\section{RESEARCH RESULT}

Shortly the research of student achievement data can see in table:

Table 1. Pretest Score and Post Test Score in Experiment Class and Control Class

\begin{tabular}{|l|c|c|c|c|}
\hline \multirow{2}{*}{ Statistic } & \multicolumn{2}{|c|}{$\begin{array}{c}\text { Experiment } \\
\text { Class }\end{array}$} & \multicolumn{2}{c|}{ Control Class } \\
\cline { 2 - 5 } & $\begin{array}{c}\text { Pre } \\
\text { Test }\end{array}$ & $\begin{array}{c}\text { Post } \\
\text { Test }\end{array}$ & $\begin{array}{c}\text { Pre } \\
\text { Test }\end{array}$ & $\begin{array}{c}\text { Post } \\
\text { Test }\end{array}$ \\
\hline $\begin{array}{l}\text { High } \\
\text { Score }\end{array}$ & 55 & 90 & 55 & 85 \\
\hline Low Score & 15 & 60 & 15 & 35 \\
\hline $\begin{array}{l}\text { Total } \\
\text { Score }\end{array}$ & 1260 & 2585 & 1280 & 2205 \\
\hline Average & 39.37 & 80.78 & 40.00 & 68.90 \\
\hline $\begin{array}{l}\text { Standard } \\
\text { Deviation }\end{array}$ & 9.13 & 8.52 & 9.98 & 10.13 \\
\hline
\end{tabular}

The result of analysis research data showed that have the effect of cooperative learning model type teams games tournament on student learning achievement on temperature and heat topic in class X SMA N 1 Berastagi. At the beginning of the research are given a pretest to experiment and control class, obtained the average of pretest of experiment class is 39.37 with standard deviation 9.13 and the average of control class is 40.00 with standard deviation is 8.98. In the normality testing for pretest obtained in experiments with $\mathrm{L}_{\text {calculate }}=0.0834$ and $\mathrm{L}_{\text {table }}=0.156$, so obtained $\mathrm{L}_{\text {count }}<$ $\mathrm{L}_{\text {table }}$, then both of classes are normally distributed. In the test homogeneity is obtained $\mathrm{F}_{\text {count }}=1.03$ and $\mathrm{F}_{\text {table }}=1.83$ so that $\mathrm{F}_{\text {count }}<\mathrm{F}_{\text {table }}$ $(1.03<1.83)$, then both of sample come from homogeneous group. Then the result of initial ability test (pretest) between experiment class and control class with similarity test two parties is obtained $-t_{\text {table }}<t_{\text {count }}<t_{\text {table }}(-1.99<-$
$0.29<1.99$ ) which means that the initial ability both of sample groups are similar.

After different treatment, the students is given the test again (posttest), the average value of posttest in experiment class using Cooperative Learning Model type Teams Games Tournament is 80.78 with standard deviation 8.52, while the average value posttest in control class with Direct Instruction is 68.90 with standard deviation is 10.13 . This research used the t test two parties to determine there were differences of samples' learning achievement when treated with Cooperative Learning Model type Teams Games Tournament in experiment class and Direct Instruction in control class. The results of hypothesis testing from the data obtained $t_{\text {count }}>t_{\text {table }}$ or $5.18>$ 1.99. At significant level $\alpha=0.05$.

Cooperative Learning Model type Teams Games Tournament not only increased student learning achievement, but also can enhance student's learning activities. From the observations made by the observers found that activity of the students gets positive increase. At the first meeting the average of student activity obtained 79.76. At the second meeting the average of students activity obtained 80.59, and the third meeting the average of students activity obtained 80.60 so it's included to good category. Whereas in a Direct Instruction Model class, activity value obtained by students is at the first meeting the average of students' activities obtained 62.05 , the second meeting the average of students' activities obtained 63.47 and the last 
the third meeting obtained 67.64. So it's included to the less category. Thus his case shows that the Cooperative Learning Model type Teams Games Tournament not only improve learning achievement, but also able to increase the students activity. So concluded is learning activity with using Cooperative learning Model type Teams Games Tournament better than the Direct Instruction Model (conventional learning)

Table 2. The average of student activity

\begin{tabular}{|c|c|c|c|c|c|}
\hline $\mathrm{N}$ & San & & Total & Average & Category \\
\hline \multirow{3}{*}{1} & \multirow{3}{*}{ EXP } & $1^{\mathrm{st}}$ & 2552.6 & 79.76 & \multirow{3}{*}{$\begin{array}{c}\text { Good } \\
\text { Category }\end{array}$} \\
\hline & & $2^{\text {nd }}$ & 2579.1 & 80.59 & \\
\hline & & $3^{\text {rd }}$ & 2579.3 & 80.60 & \\
\hline \multirow{3}{*}{2} & \multirow{3}{*}{$\mathrm{Co}$} & $1^{\mathrm{st}}$ & 1698.3 & 62.05 & \multirow{3}{*}{$\begin{array}{c}\text { Less } \\
\text { Category }\end{array}$} \\
\hline & & $2^{\text {nd }}$ & 2031.3 & 63.47 & \\
\hline & & $3^{\text {rd }}$ & 2164.5 & 67.64 & \\
\hline
\end{tabular}

\section{Hypothesis Test of Post-test}

Hypothesis testing is a requirement that is used to determine whether the $\mathrm{Ha}$ in the research accepted or rejected. The data used to know the different of student ability after have treatment.

Table3. Hypothesis Test of Post-Test Data

\begin{tabular}{|l|c|c|c|c|}
\hline \multicolumn{1}{|c|}{ Data } & $\begin{array}{c}\text { Averag } \\
\mathbf{e}\end{array}$ & $\begin{array}{c}\mathrm{t}_{\text {coun }} \\
\mathrm{t}\end{array}$ & $\begin{array}{c}\mathrm{t}_{\text {tabl }} \\
\mathbf{e}\end{array}$ & $\begin{array}{c}\text { Conclusio } \\
\mathbf{n}\end{array}$ \\
\hline $\begin{array}{l}\text { Experimen } \\
\text { t Class }\end{array}$ & 80.78 & 5.18 & 1.99 & $\begin{array}{c}\text { Have } \\
\text { different } \\
\text { significan } \\
\mathrm{t}\end{array}$ \\
\hline $\begin{array}{l}\text { Control } \\
\text { Class }\end{array}$ & 68.90 & & & \begin{tabular}{c} 
\\
\hline
\end{tabular}
\end{tabular}

The results of hypothesis testing two parties on the post test with $\alpha=$ 0.05 obtained the price $t_{\text {count }}=5.18$ and $t_{\text {table }}=1.99$. By comparing $t_{\text {count }}$ and $t_{\text {table }}$ obtained $t_{\text {count }}>t_{\text {table }}$ it's $5.18>$ 1.99 so Ho rejected and $\mathrm{Ha}$ accepted. Can be concluded have effect of Cooperative Learning Model type Teams Games Tournament for student achievement on Heat and Temperature topic in class $\mathrm{X}$ in SMA $\mathrm{N} 1$ Berastagi Academic Year 2012/2013. After given treatment in Experiment class with Cooperative Learning Model type Teams Games Tournament have a score average is 80.415 with standard deviation is 9.28. While in Control class after given treatment with Direct Instruction Model has score average 68.90 with standard deviation is 10.1. The comparison of posttest value in 2 of classes can see in table 4.3 below:

Table 4.6 Post-Test Data in Experiment Class and Control Class

\begin{tabular}{|c|c|c|c|c|c|c|c|}
\hline \multicolumn{4}{|c|}{ Experiment Class } & \multicolumn{4}{|c|}{ Control Class } \\
\hline $\mathrm{V}$ & $\mathrm{F}$ & A & $\mathrm{S}$ & $\mathrm{V}$ & $\mathrm{F}$ & A & $\mathrm{S}$ \\
\hline 60 & 2 & \multirow{9}{*}{80.78} & \multirow{9}{*}{8.52} & 50 & 4 & \multirow{9}{*}{68.90} & \multirow{9}{*}{10.1} \\
\hline 65 & 1 & & & 55 & 0 & & \\
\hline 70 & 1 & & & 60 & 5 & & \\
\hline 75 & 7 & & & 65 & 3 & & \\
\hline 80 & 3 & & & 70 & 6 & & \\
\hline 85 & 11 & & & 75 & 8 & & \\
\hline 90 & 7 & & & 80 & 4 & & \\
\hline & & & & 85 & 2 & & \\
\hline & & & & $\mathrm{T}=$ & 32 & & \\
\hline
\end{tabular}

\section{CONCLUSION AND SUGGESTION} Conclusion

Based on result research and data collection, can be concluded that student activity frequency in experiment class have Cooperative Learning Model type Teams Games Tournament after three times meeting concluded to good category. While the students activity in control class have direct Instruction Model after three 
times meeting is concluded to less category. Their pretest value in experiment class has Cooperative Learning Model type Teams Games Tournament concluded to low category. In control class has the Direct Instruction model conclude to low category. While the student posttest value in experiment class has Cooperative Learning Model type Teams Games Tournament it's concluded to good category. While in control class has the Direct Instruction model it's concluded to enough categories, And the effect of Cooperative Learning Model Type Teams Games Tournament on student's achievement on Temperature and Heat topic in class X SMA N 1 Berastagi Academic Year 2012/2013. It means Cooperative Learning Model Type Teams Games Tournament better than Direct Instruction Model to increase of student achievement.

\section{Suggestion}

Based on discussion of research result and conclusion above, writer give suggestions for further researcher who wants to observe using Cooperative Model Type Teams Games Tournament, observer must make students more active in tournament phase, to do more efficiently may using a media in learning process, so can increased of student achievement, and should more make the experiments and observations can be implemented, it would require the creativity of teachers to design and create a simple lab instruments.

\section{REFFERENCE}

Abdullah M, R, 2009. A study on Effect of Science Activities on Fostering Creativity in Preschool Children Volume 6: Turkish Science Educational

Fidelia, N, 2009. Cooperative Learning Aproach and Student's Achievement in Sociology Volume 3: An International MultyDisciplinary Journal Ethiopia

Johnson, D and Roger T, 2009. An Educational Psychology Success Story: Social Interdependence Theory and Cooperative Learning. America: American Educational Research Association

Joyce, B, 2004. Models of Teaching. New Jersey: Prentice/Hall International. Ing

Kanginan, M, 2007. Fisika SMA untuk Kelas $X$. Cimahi: Aksara Pratama

Long, M, 2000. The Psychology of Education. London and New York: Routledge

Olarewaju, A, 2012. Achievement in Cooperative versus Individualistic goal structured junior secondary school Mathematics Clasroom in Nigeria Volume 3 : International Jurnal of Matematics and Tren Technology.

Purwanto, B, 2009. Theory and Application of Physics. Solo: Tiga Serangkai

Purwnato, N.2009. Prinsip-prinsip dan teknik evaluasi pembelajaran. Jakarta: Remaja Rosdakarya 
Sadirman, A, 2009. Interaksi dan Motivasi Belajar Mengajar. Jakarta: PT. Raja Grapindo Persada

Sanjaya, W, 2006. Strategi Pembelajaran. Jakarta: Kencana

Sanjaya, W, 2009. Strategi Pembelajaran Berorientasi Standar Proses Pendidikan. Jakarta: Kencana

Seligman, M, 2009. Positive Education: Positive Psychology and Classroom Interventions. USA: Routledge

Slavin, R. E, 2005. Cooperative Learning: (theory, research and practice). London: Allymand Bascon 